\title{
Job burnout and self-efficacy survey among elementary school teachers in Greece
}

\author{
Maria-Christina Tzioti, Eleftheria Mantelou, Nick E Degleris, Andreas Solias, Manto Karamberi, Niki Romanou \\ From $1^{\text {st }}$ International Congress on Neurobiology and Clinical Psychopharmacology \\ and European Psychiatric Association Conference on Treatment Guidance \\ Thessaloniki, Greece. 19-22 November 2009
}

\section{Background}

Emotional exhaustion, depersonalization and reduced professional efficacy within the workplace are the three dimensions of the job burnout syndrome. In this study, we examined the levels of job burnout in a sample of 100 teachers of elementary education. Also, we sought to identify the relationship between job burnout and general self-efficacy, teachers' self-efficacy and group self-efficacy. Moreover, we looked into the relationship between job burnout and the three types of self-efficacy with teachers' perceptions of particular work-related values. Job burnout dimensions and self-efficacy are also studied in relation to teachers' demographic characteristics.

\section{Materials and methods}

Job burnout was measured using the Maslach Burnout Inventory (Educators Survey) [1]. Self-efficacy was measured with the Shwarzer and Jerusalem's [2] questionnaire. The work values questionnaire was makeshift and answers were given on a 6-point scale.

\section{Results}

Female teachers presented higher levels of job burnout, whereas teachers over 50 years old presented higher levels of self-efficacy than those between $31-40$ years old. The three types of self-efficacy were negatively correlated with the three job burnout dimensions.

\section{Conclusions}

In particular, this research stresses the importance of the relationship between group self-efficacy and job burnout. What is more, job burnout seems to have an impact on people's perceptions about their occupation.

Psychotherapeutic Center of Piraeus, Greece
Moreover, it would be interesting to study the relationship between self-efficacy and job burnout in other professional groups as well.

Published: 22 April 2010

\section{References}

1. Maslach C, Jackson SE, Leiter MP: Maslach Burnout Inventory. Manual. Palo Alto, CA: Consulting Psychologists Press, 31996.

2. Schwarzer R: Measurement of perceived self-efficacy. Psychometric scales for cross-cultural research Berlin, Germany: Freie Univesität Berlin 1993.

3. Bandura A: Self- efficacy: Toward a unifying theory of behavioral change. Psychological Review 1977, 84:191-215.

4. Bandura A, Cervone D: Self- evaluative and self-efficacy mechanisms governing the motivational effects of goal systems. Journal of Personality and Social Psychology 1983, 45:1017-1028.

doi:10.1186/1744-859X-9-S1-S192

Cite this article as: Tzioti et al:: Job burnout and self-efficacy survey among elementary school teachers in Greece. Annals of General Psychiatry 2010 9(Suppl 1):S192.
Submit your next manuscript to BioMed Central and take full advantage of:

- Convenient online submission

- Thorough peer review

- No space constraints or color figure charges

- Immediate publication on acceptance

- Inclusion in PubMed, CAS, Scopus and Google Scholar

- Research which is freely available for redistribution

Submit your manuscript at www.biomedcentral.com/submit
C Biomed Central 